\title{
EVALUASI KESESUAIAN LAHAN CABAI MERAH DI KAWASAN RELOKASI SIOSAR KABUPATEN KARO
}

\section{The Evaluation of Suitability of Land in the Area of Red Chilies Peppers Relocation Siosar Karo Regency}

\author{
Agustoni Tarigan $^{1 *}$, Abdul Rauf ${ }^{2 *}$, Rahmawaty $^{2 *}$ \\ Program Studi Pascasarjana, Fakultas Pertanian, USU, Medan \\ Penulis korespondensi: agustonitarigan@ymail.com
}

\begin{abstract}
Siosar relocation Region is located in the Subdistrict Merek in Karo with an altitude between 1490 $1562 \mathrm{~m}$ above sea level. With this type of soil Andisol where land is hilly and undulating with a slope of $+37.5 \%$ and the climate type D3, leasing land from the Ministry of Environment and Forests covering an area of 414.44 ha reserved for heads of household 370 victims of the eruption of Mount Sinabung, through Decree of the Minister of the Environment life and Forestry No. SK.107 / MenLHK-II / 2015. This study aimed to evaluate the characteristics of the level of production forest land suitability for the cultivation of chilli in the Region Siosar, to analyze the remedial efforts that need to be done in improving crop productivity, and to create maps of the actual land suitability and potential land suitability chilli plants. The method used was a survey method. Unit of land based on soil map consisted of 7 units of land analysis were used for matching. The results showed that the level of potential land suitability for chilli plant (Capsicum annum) included marginally suitable (S3) covering an area of 297,3 ha and quite suitable (S2) covering 117,14 ha.
\end{abstract}

Keywords: land suitability, Mount Sinabung, potatoes, relocation

\section{Pendahuluan}

Kawasan relokasi Siosar merupakan kawasan ex.hutan produksi yang diberi izin pinjam pakai oleh Kementerian Lingkungan Hidup dan Kehutanan Republik Indonesia sesuai Surat Keputusan Nomor SK.107/MenLHK-II/2015. Yang diperuntukkan bagi masyarakat terdampak urupsi gunung Sinabung, selama 20 tahun seluas 414,44 ha. Evaluasi lahan untuk keperluan perencanaan memiliki peran penting karena hampir tidak ada aktifitas yang dilakukan tanpa daya dukung lahan. Berdasarkan UU No. 24 tahun 1992 pemerintah menyarankan agar kegiatan evaluasi lahan di adakan secara luas sebagai kebijakan perencanaan kawasan indonesia, evaluasi kesesuaian lahan diharapkan memperoleh datadata karakteristik lahan yang menunjukkan sifat-sifat lahan sehingga dapat diketahui tingkat kesesuaian lahannya yang kemudian dilakukan upaya-upaya perbaikan yang sesuai dengan karakteristik lahan yang pada akhirnya akan mengoptimalkan produksi tanaman. FAO (1976), mengemukakan bahwa untuk dapat berproduksi optimal tanaman membutuhkan persyaratan tumbuh tertentu. Disamping itu, agar dapat tumbuh dan berproduksi tinggi serta hasilnya berkualitas maka tanaman harus dibudidayakan pada lingkungan yang sesuai (Mubekti, 2012). Kawasan hutan produksi Siosar merupakan lahan kering bekas hutan pinus yang menyisakan banyak permasalahan, yaitu ; 1) pencabutan tunggul pohon pinus, 2) masalah alelopati, 3) pemilihan komoditas, 4) lahan berlereng (2,5-37,5\%), serta 5) kemasaman dan kesuburan tanah (Tarigan, 2015). Dengan demikian penelitian ini 
dilakukan untuk mendukung kebijakan pemerintah dan informasi bagi masyarakat petani sehingga pengelolaan tanaman cabai merah dapat dilakukan secara optimal.

\section{Bahan dan Metode}

Secara administratif areal relokasi Siosar termasuk kedalam wilayah Desa Nagara, Kecamatan Merek. Secara geografis terletak antara 2०58'15“LU, 98\%26“48“BT sampai 3०00`01“'LU 98०27'27“BT, dengan Luas areal $414,44 \mathrm{Ha}$. Dengan ketinggian tempat 1476 $1562 \mathrm{~m}$ dpl dengan kemiringan lereng 2,5 $37,5 \%$ (Gambar 1), memiliki curah Hujan 1.126-1.849 $\mathrm{mm} /$ tahun, Temperatur ratarata tahunan 17,25 ${ }^{\circ} \mathrm{C}$ dan Kelembaban $89 \%$ (Data dari Dinas Pertanian dan Perkebunan Kabupaten Karo).

Penelitian ini dilakukan dengan menggunakan metoda survei yang terdiri dari lima tahap yaitu persiapan, pra-survei, survei utama, analisis tanah di Laboratorium serta pengolahan data. Pengambilan sampel tanah dilakukan dengan cara pemboran pada areal satuan lahan. Satuan lahan yang di pilih berdasarkan peta satuan unit penggunaan lahan. Terdapat sebanyak 25 titik sampel setelah dikompositkan (Gambar 2). Penentuan nilai karakteristik lahan untuk sampel tanah dilakukan dengan menggunakan bor tanah pada kedalaman 0-20 cm , 20 - 40 dan 40-60 $\mathrm{cm}$. Penentuan sifat kimia tanah dilakukan dengan analisa tanah di Laboratorium SOCFINDO Bangun Bandar Dolok Masihol serta penentuan Biologi tanah di Laboratorium Biologi Tanah USU Medan. Data yang diperoleh selanjutnya diinterpretasikan ke dalam kriteria tingkat kesuburan tanah dan diinterpretasikan ke dalam kelas kesesuaian lahan menurut Sys et al. (1993) dan Puslittan (1995).

Proses evaluasi lahan ditentukan dengan cara matching (mencocokkan) antara karakteristik lahan dengan persyaratan tumbuh tanaman cabai merah yang di formulasikan dalam petunjuk teknis evaluasi lahan untuk Komoditas Pertanian (Hardjowigeno, 2007; Ritung et al., 2011). Pada proses matching di gunakan hukum minimum Leibig untuk menentukan faktor pembatas yang akan mempengaruhi kelas dan sub kelas kesesuaian lahannya. Hasil kesesuaian lahan masingmasing komoditas tanaman ditampilkan dalam bentuk tabel kesesuaian lahan aktual dan potensial menggunakan perangkat lunak GIS. Selanjutnya dipetakan kesesuaian lahan aktual dan kesesuian lahan potensialnya.

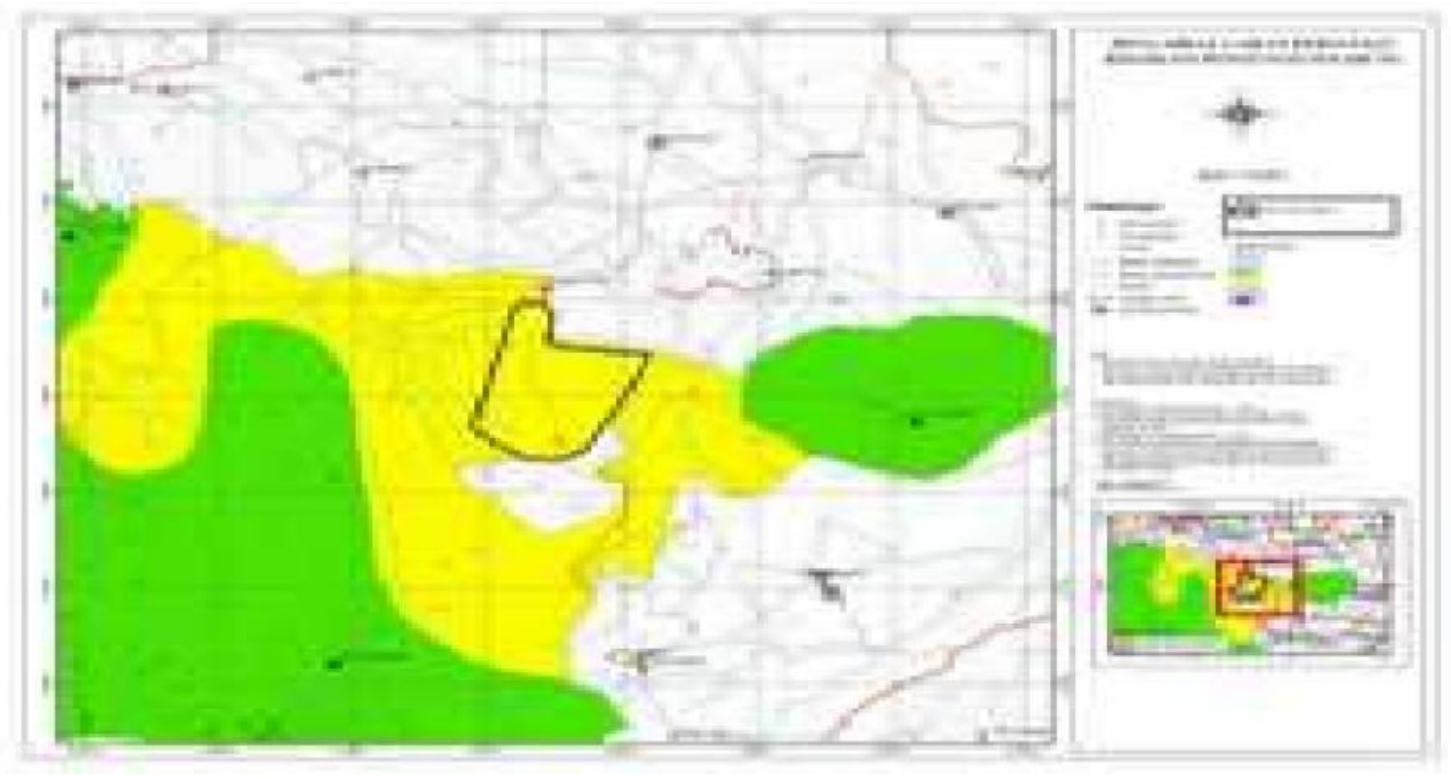

Gambar 1. Peta Lokasi Penelitian 


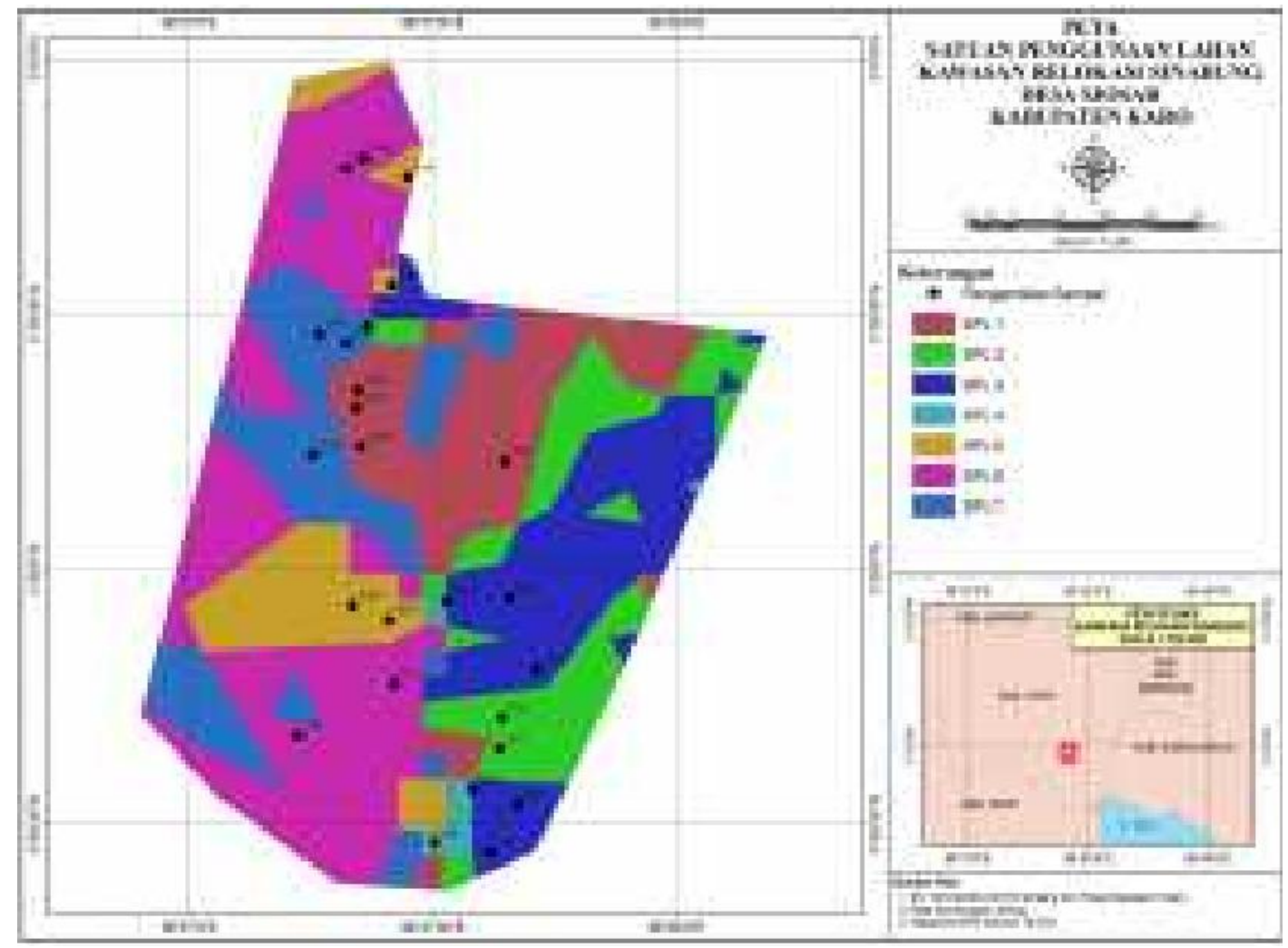

Gambar 2. Titik pemboran sampel tanah

\section{Hasil dan Pembahasan}

\section{Karakteristik lahan}

Karakteristik lahan pertanian di kawasan relokasi Siosar yang sebelumnya merupakan kawasan Hutan Produksi Pinus, dikelompokkan ke dalam 7 (tujuh) unit lahan (land unit) dengan karakteristik lahan masing-masingnya disajikan pada Tabel 1. Dengan Jenis tanah Andisol, greatgroup Hapludands dominan yang terbentuk dari bahan induk abu vulkanis gunung Toba.

Klasifikasi iklim Oldeman dengan zone iklim D3, yang mempunyai karakteristik 3 - 4 bulan basah dan 4 - 6 bulan kering secara berturut-turut, sehingga hanya mungkin melakukan satu kali tanam padi atau satu kali palawija setahun tergantung pada ketersediaan air. Zona agroekosistem ini merupakan kawasan Hutan dengan bentuk wilayah berbukit, mempunyai kemiringan lereng $+37,5$ $\%$. Karakteristik fisik tanah yang mempengaruhi perakaran tanaman seperti tekstur, drainase dan kedalaman perakaran termasuk cukup baik yaitu drainase tanah agak terhambat - baik, tekstur lempung liat berpasir dan kedalaman efektif hingga $>100 \mathrm{~cm}$. Nilai $\mathrm{pH}$ tanah bervariasi dari 4.5 sampai 5.6 (masam), Nilai N-total tanah sedang sampai sangat tinggi. Nilai $\mathrm{P}$ - tersedia rata-rata tergolong sangat tinggi. Sedangkan $\mathrm{K}$-tukar tanah rata-rata tergolong rendah, C-Organik tergolong tinggi sehingga tidak seluruh unit lahan perlu penambahan bahan organik.

Nilai KTK rata-rata sedang, dengan nilai yang sedang tanah mampu menyerap dan menyediakan unsur hara yang lebih banyak dari pada tanah dengan KTK yang lebih rendah. Kejenuhan basa di wilayah ini termasuk dalam golongan sedang. KTK dan Kejenuhan Basa merupakan indikator kesuburan kimia tanah. Tanah yang subur adalah tanah dengan kejenuhan basa tinggi sebab belum terjadi pencucian tanah yang serius. Sebaliknya, tanah dengan kejenuhan basa rendah menandakan tanah tersebut asam sehingga menghambat penyerapan unsur hara oleh akar tanaman (Indranada, 1986). 
Tabel 1. Karakteristik lahan budidaya cabai merah di kawasan relokasi Siosar.

\begin{tabular}{|c|c|c|c|c|c|c|c|}
\hline \multirow{2}{*}{$\begin{array}{l}\text { Karakteristik } \\
\text { Lahan }\end{array}$} & \multicolumn{7}{|c|}{ Unit Lahan } \\
\hline & 1 & 2 & 3 & 4 & 5 & 6 & 7 \\
\hline $\begin{array}{l}\text { Temperatur } \\
\text { ratarata tahunan } \\
\left({ }^{\circ} \mathrm{C}\right)\end{array}$ & 17,25 & 17,25 & 17,25 & 17,25 & 17,25 & 17,25 & 17,25 \\
\hline Zona Agroklimat & D3 & D3 & D3 & D3 & D3 & D3 & D3 \\
\hline Kelembaban (\%) & 89 & 89 & 89 & 89 & 89 & 89 & 89 \\
\hline $\begin{array}{l}\text { Curah hujan } \\
\text { tahunan }(\mathrm{mm})\end{array}$ & 1607 & 1607 & 1607 & 1607 & 1607 & 1607 & 1607 \\
\hline Ketinggian (m dpl) & 1524 & 1524 & 1492 & 1476 & 1504 & 1490 & 1562 \\
\hline Drainase & Baik & $\begin{array}{c}\text { Agak } \\
\text { terhambat }\end{array}$ & $\begin{array}{c}\text { Agak } \\
\text { terhambat }\end{array}$ & $\begin{array}{c}\text { Agak } \\
\text { terhambat }\end{array}$ & $\begin{array}{c}\text { Agak } \\
\text { terhambat }\end{array}$ & $\begin{array}{c}\text { Agak } \\
\text { terhambat }\end{array}$ & Baik \\
\hline Tekstur & $\begin{array}{l}\text { Lempung } \\
\text { berpasir }\end{array}$ & $\begin{array}{l}\text { Lempung } \\
\text { liat } \\
\text { berpasir }\end{array}$ & $\begin{array}{l}\text { Lempung } \\
\text { liat } \\
\text { berpasir }\end{array}$ & $\begin{array}{l}\text { Lempung } \\
\text { berpasir }\end{array}$ & $\begin{array}{l}\text { Lempung } \\
\text { berpasir }\end{array}$ & $\begin{array}{l}\text { Lempung } \\
\text { liat } \\
\text { berpasir }\end{array}$ & $\begin{array}{l}\text { Lempung } \\
\text { berpasir }\end{array}$ \\
\hline $\begin{array}{l}\text { Kedalaman efektif } \\
(\mathrm{cm})\end{array}$ & $>100$ & $>100$ & $>100$ & $>100$ & $>100$ & $>100$ & $>100$ \\
\hline $\mathrm{pH}$ Tanah & $5,3(\mathrm{M})$ & $5,6(\mathrm{AM})$ & 4,8 (M) & 4,9 (M) & $5,1(\mathrm{M})$ & $5,1(\mathrm{M})$ & $5,2(\mathrm{M})$ \\
\hline C-organik (\%) & 6,6 (ST) & $3,1(\mathrm{~T})$ & $2,1(\mathrm{~S})$ & $2,4(\mathrm{~S})$ & $3,4(\mathrm{~T})$ & $3,9(\mathrm{~T})$ & $4(\mathrm{~T})$ \\
\hline $\mathrm{N}$-total $(\%)$ & 0,76 (ST) & $0,58(\mathrm{~T})$ & $0,26(\mathrm{~S})$ & $0,24(\mathrm{~S})$ & $0,63(\mathrm{~T})$ & $0,58(\mathrm{~T})$ & $0,76(\mathrm{ST})$ \\
\hline $\begin{array}{l}\mathrm{P}_{2} \mathrm{O}_{5} \text { Bray I } \\
(\mathrm{mg} / 100 \mathrm{~g})\end{array}$ & $5,74(\mathrm{SR})$ & 4,61 (SR) & 2,25 (SR) & 2,29 (SR) & 3,84 (SR) & 4,03 (SR) & 8,91 (SR) \\
\hline $\begin{array}{l}\text { Kejenuhan Basa } \\
(\%)\end{array}$ & $64.95(\mathrm{~T})$ & $72.90(\mathrm{~T})$ & $49,70(\mathrm{~S})$ & 35,93 (R) & $44,87(\mathrm{~S})$ & $44,12(\mathrm{~S})$ & $45,92(\mathrm{~S})$ \\
\hline KTK (me/100g) & $20,89(\mathrm{~S})$ & $14,47(\mathrm{R})$ & $20,15(\mathrm{~S})$ & $27,99(\mathrm{~T})$ & $23,73(\mathrm{~S})$ & $23,90(\mathrm{~S})$ & $24,37(\mathrm{~S})$ \\
\hline $\begin{array}{l}\text { K-tukar (me/100 } \\
\text { g) }\end{array}$ & $0,26(\mathrm{R})$ & $0,18(\mathrm{R})$ & $0,18(\mathrm{R})$ & $0,15(\mathrm{R})$ & $0,26(\mathrm{R})$ & $0,19(\mathrm{R})$ & $0,13(\mathrm{R})$ \\
\hline $\begin{array}{l}\text { Ca-tukar (me/100 } \\
\text { g) }\end{array}$ & $12,68(\mathrm{~T})$ & $9,29(\mathrm{~S})$ & $9,33(\mathrm{~S})$ & $9,44(\mathrm{~S})$ & $10,1(\mathrm{~S})$ & $10,23(\mathrm{~S})$ & $10,08(\mathrm{~S})$ \\
\hline $\begin{array}{l}\text { Mg-tukar (me/100 } \\
\text { g) }\end{array}$ & $0,66(\mathrm{R})$ & $0,54(\mathrm{R})$ & $0,55(\mathrm{R})$ & 0,38 (SR) & 0,37 (SR) & $0,51(\mathrm{R})$ & 0,18 (SR) \\
\hline $\begin{array}{l}\text { Na-tukar (me/100 } \\
\text { g) }\end{array}$ & $0,00(\mathrm{SR})$ & $0,14(\mathrm{R})$ & 0,08 (SR) & $0,11(\mathrm{R})$ & $0,13(\mathrm{R})$ & 0,01 (SR) & 0 (SR) \\
\hline Lereng $(\%)$ & 2,5 & 3 & 6 & 3 & 22,5 & 37,5 & 3 \\
\hline $\begin{array}{l}\text { Batuan } \\
\text { dipermukaan }(\%)\end{array}$ & 0 & 0 & 0 & 0 & 0 & 0 & 0 \\
\hline $\begin{array}{l}\text { Singkapan batuan } \\
(\%)\end{array}$ & 0 & 0 & 0 & 0 & 0 & 0 & 0 \\
\hline Bahaya Banjir & F0 & F0 & F0 & F0 & F0 & F0 & F0 \\
\hline $\begin{array}{l}\text { Total Mikroba } \\
\text { (cfu) }\end{array}$ & $3,0 \times 10^{7}$ & $2,5 \times 10^{7}$ & $4,5 \times 10^{7}$ & $1,5 \times 10^{7}$ & $1,5 \times 10^{7}$ & $4,5 \times 10^{6}$ & $2,5 \times 10^{8}$ \\
\hline
\end{tabular}

Keterangan: $\mathrm{ST}=$ sangat tinggi, $\mathrm{R}=$ rendah $\quad, \mathrm{T}=$ tinggi, $\mathrm{S}=$ sedang, $\mathrm{SR}=$ sangat rendah, $\mathrm{F} 0=$ tidak ada banjir, $\mathrm{M}=$ masam

\section{Kelas kesesuaian lahan pertanian relokasi Sinabung}

Penilaian kelas kesesuaian lahan pada Kawasan Hutan Produksi Siosar yang akan dijadikan lahan budidaya cabai merah bagi pengungsi erupsi gunung Sinabung dilakukan pada setiap unit lahan. Dari Tabel 2, arakteristik ketersediaan hara $\mathrm{K}_{2} \mathrm{O}$ tanah dan kemiringan lereng pada areal pertanian relokasi Siosar untuk tanaman cabai merah (Capsicum annum) tergolong rendah. Hal ini bukan faktor pembatas utama karena masih bisa dilakukan pengelolaan dengan penambahan unsur hara ke dalam tanah dan melakukan tindakan konservasi berupa pembuatan teras maupun penanaman sejajar kontur serta melakukan system pertanaman zigzag sehingga unsur hara dan tanah tidak mudah tercuci ketika terjadi curah hujan yang cukup tinggi. Faktor 
pembatas utama dalam penilaian kelas kesesuaian lahan untuk tanaman Cabai merah
(Capsicum annum) adalah media perakaran berupa tekstur tanah.

Tabel 2. Rekapitulasi kesesuaian lahan dan upaya perbaikan yang dilakukan pada budidaya tanaman cabai merah (Capsicum annum).

\begin{tabular}{|c|c|c|c|}
\hline Land Unit & KLA & Perkiraan Usaha Perbaikan & KLP \\
\hline Unit lahan 1 & $\begin{array}{l}\text { S3-wa, rc, } \\
\text { nr }\end{array}$ & $\begin{array}{l}\text { Pengapuran 2,1 ton CaCO3/ha } \\
\text { Pemupukan } 49 \mathrm{~kg} \mathrm{~K} 2 \mathrm{O} / \mathrm{ha} \text { atau } 82,33 \mathrm{~kg} \mathrm{KCl} / \mathrm{ha} \\
\text { Pemupukan } 169 \mathrm{~kg} \mathrm{P} 2 \mathrm{O} 5 / \mathrm{ha} \text { atau } 470 \mathrm{~kg} \mathrm{SP} 36 / \mathrm{ha} \\
\text { Pembuatan drainase }\end{array}$ & S3-wa, rc \\
\hline Unit lahan 2 & S3-wa,tc & $\begin{array}{l}\text { Pembuatan Drainase } \\
\text { Pemupukan } 70 \mathrm{~kg} \mathrm{~K} 2 \mathrm{O} / \mathrm{ha} \text { atau } 117 \mathrm{~kg} \mathrm{KCl} / \mathrm{ha} \\
\text { Pemberian B.Organik } 5.34 \text { ton/ha atau } 25 \mathrm{ton} / \mathrm{ha} \text { pupuk } \\
\text { Organik } \\
\text { Pemupukan } 171 \mathrm{~kg} \text { P2O5/ha atau } 475 \mathrm{~kg} \mathrm{SP} 36 / \mathrm{ha} \\
\text { Penanaman sejajar kontur, dan system pertanaman Zigzag. }\end{array}$ & S2-wa, tc \\
\hline Unit lahan 3 & S3-wa, nr & $\begin{array}{l}\text { Pembuatan Drainase } \\
\text { Pengapuran 2,1 ton CaCO3/ha } \\
\text { Pemupukan } 176 \mathrm{~kg} / \mathrm{ha} \mathrm{P} 2 \mathrm{O} 5 \text { atau } 500 \mathrm{~kg} / \mathrm{ha} \mathrm{SP} 36 \\
\text { Pemupukan } 70 \mathrm{~kg} \mathrm{~K} 2 \mathrm{O} / \mathrm{ha} \text { atau } 117 \mathrm{~kg} \mathrm{KCl} / \mathrm{ha}\end{array}$ & S2-wa \\
\hline Land unit 4 & S3- wa,nr,rc & $\begin{array}{l}\text { Pengapuran 2,1 ton CaCO3/ha } \\
\text { Pemupukan } 176 \mathrm{~kg} / \mathrm{ha} \mathrm{P} 2 \mathrm{O} 5 \text { atau } 486 \mathrm{~kg} / \mathrm{ha} \mathrm{SP} 36 \\
\text { Pemupukan } 78 \mathrm{~kg} \mathrm{~K} 2 \mathrm{O} / \mathrm{ha} \text { atau } 130 \mathrm{~kg} \mathrm{KCl} / \mathrm{ha} \\
\text { Penanaman sejajar kontur, Pembuatan drainase dan system } \\
\text { pertanaman Zigzag. }\end{array}$ & S3-rc \\
\hline Unit lahan 5 & N-eh & $\begin{array}{l}\text { Pengapuran 2,1 ton CaCO3/ha } \\
\text { Pemupukan } 49 \mathrm{~kg} \mathrm{K2O} / \mathrm{ha} \text { atau } 82,33 \mathrm{~kg} \mathrm{KCl} / \mathrm{ha} \\
\text { Pemupukan } 176 \mathrm{~kg} / \mathrm{ha} \text { P2O5 atau } 486 \mathrm{~kg} / \mathrm{ha} \mathrm{SP} 36 \\
\text { Pembuatan teras maupun penanaman sejajar kontur, } \\
\text { pembuatan drainase dan system pertanaman Zigzag. }\end{array}$ & S3-rc, eh \\
\hline Unit lahan 6 & N-eh & $\begin{array}{l}\text { Pengapuran 2,1 ton CaCO3/ha } \\
\text { Pemupukan } 68 \mathrm{~kg} \mathrm{K2O} / \mathrm{ha} \text { atau112,67 kg KCl} / \mathrm{ha} \\
\text { Pemupukan } 172 \mathrm{~kg} / \mathrm{ha} \mathrm{P} 2 \mathrm{O} 5 \text { atau } 478 \mathrm{~kg} / \mathrm{ha} \mathrm{SP} 36 \\
\text { Pembuatan teras maupun penanaman sejajar kontur, } \\
\text { Pembuatan drainase dan system pertanaman Zigzag. }\end{array}$ & S3-eh \\
\hline Unit lahan 7 & $\begin{array}{l}\text { S3-wa, rc, } \\
\text { nr }\end{array}$ & $\begin{array}{l}\text { Pengapuran } 2,1 \text { ton CaCO } 3 / \mathrm{ha} \\
\text { Pemupukan } 83 \mathrm{~kg} \mathrm{~K} 2 \mathrm{O} / \mathrm{ha} \text { atau } 138,67 \mathrm{~kg} \mathrm{KCl} / \mathrm{ha} \\
\text { Pemupukan } 162 \mathrm{~kg} / \mathrm{ha} \text { P2O } 5 \text { atau } 450 \mathrm{~kg} / \mathrm{ha} \mathrm{SP} 36 \\
\text { Penanaman sejajar kontur, Pembuatan drainase dan system } \\
\text { pertanaman Zigzag. }\end{array}$ & S2-rc \\
\hline
\end{tabular}

Keterangan $:$ KLA = Kesesuaian Lahan Aktual, KLP = Kesesuaian Lahan Potensial

Tekstur tanah tidak akan berubah dalam waktu yang singkat, contohnya tekstur pasir sulit dirubah menjadi lempung atau tekstur liat sulit dirubah menjadi pasir. Hal ini didukung oleh Rayes (2007) yang menyatakan bahwa dalam evaluasi lahan dengan faktor media perakaran berupa tekstur tidak dapat dilakukan usaha perbaikan. Dari hasil analisis yang di peroleh dapat dilihat pada Tabel 2. Dari hasil analisis GIS diperoleh luas kesesuaian lahan aktual dan potensial pada areal pertanian relokasi Sinabung untuk tanaman Cabai merah (Capsicum annum) (Tabel 3) dan peta kesesuaian lahannya disajikan pada Gambar 3 dan 4. 
Jurnal Tanah dan Sumberdaya Lahan Vol 6 No 2 : 1229-1235, 2019

e-ISSN:2549-9793, doi: 10.21776/ub.jts1.2019.006.2.3

Tabel 3. Luas kesesuaian lahan untuk tanaman Cabai merah (Capsicum annum).

\begin{tabular}{ccccc}
\hline $\begin{array}{c}\text { Unit } \\
\text { Lahan }\end{array}$ & $\begin{array}{c}\text { Kesesuaian lahan } \\
\text { aktual }\end{array}$ & $\begin{array}{c}\text { Kesesuaian lahan } \\
\text { potensial }\end{array}$ & Luas (ha) & Persentase (\%) \\
\hline 1 & S3 (wa,rc,nr) & S3 (rc) & 72,17 & 17,41 \\
2 & S3 (wa,tc, & S2 (wa,tc) & 52,65 & 12,70 \\
3 & S3 (wa,nr) & S2 (wa) & 64,49 & 15,56 \\
4 & S3 (wa,rc,nr) & S3 (rc) & 63,85 & 15,41 \\
5 & N (eh) & S3 (rc,eh) & 37,27 & 8,99 \\
6 & N (eh) & S3 (eh) & 119,27 & 28,78 \\
7 & S3 (wa,rc,nr) & S2 (rc) & 4,74 & 1,14 \\
\hline \multicolumn{7}{c}{ Total } & $\mathbf{4 1 4 , 4 4}$ & $\mathbf{1 0 0 , 0 0}$ \\
\hline
\end{tabular}

Sumber : Hasil analisis GIS.

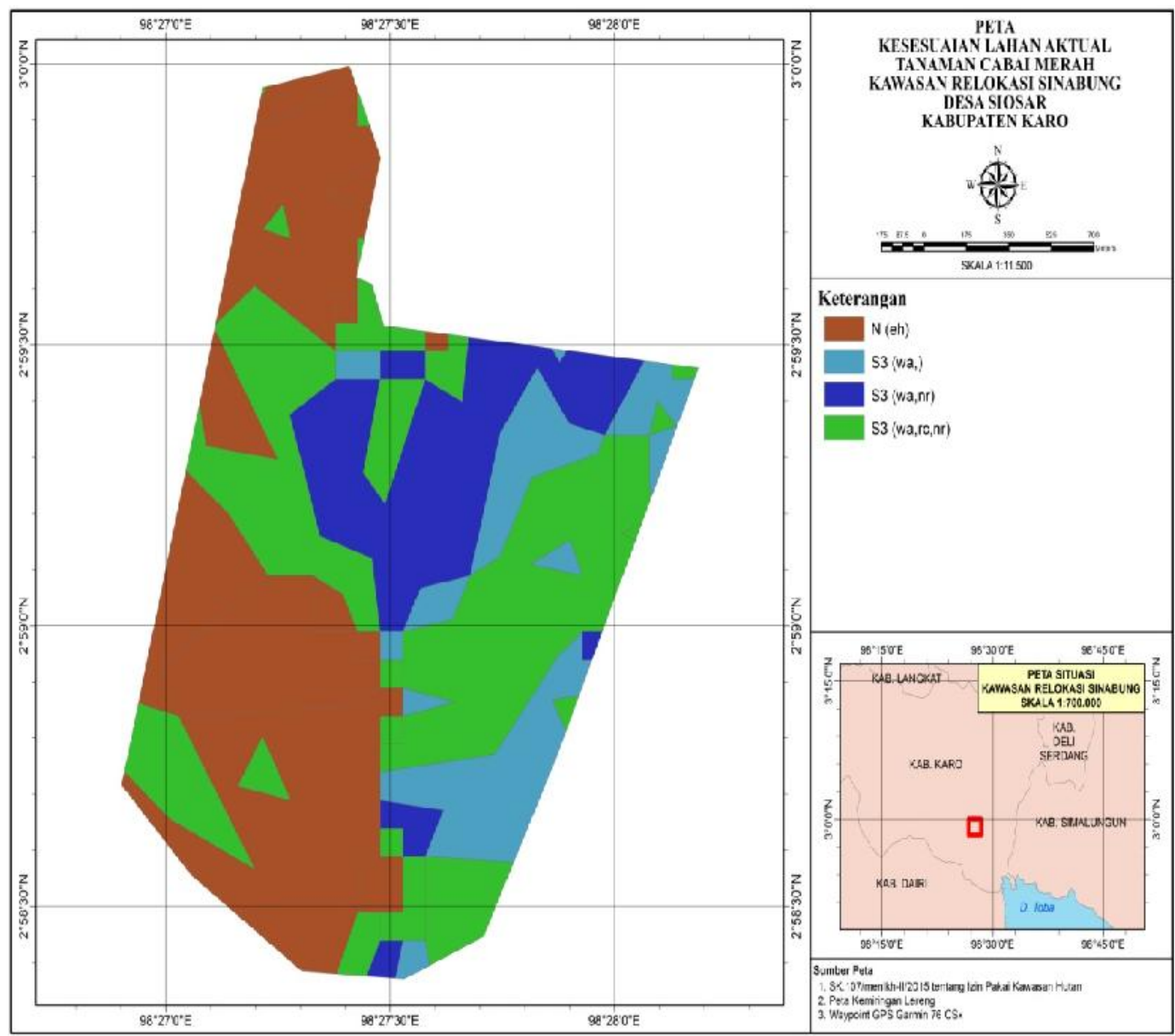

Gambar 3. Peta kesesuaian lahan Aktual 


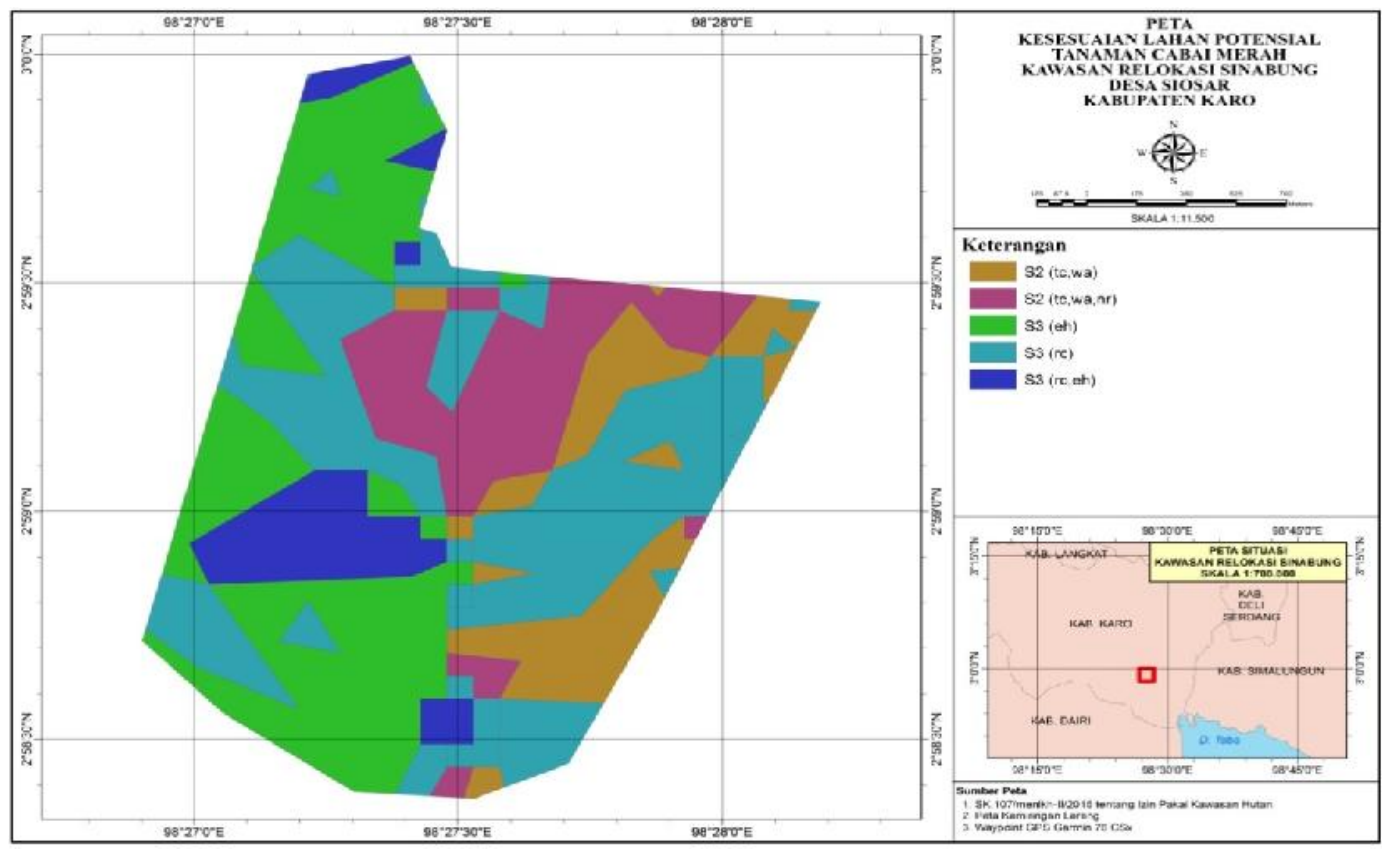

Gambar 4. Peta Kesesuaian lahan potensial

\section{Kesimpulan}

Kelas kesesuaian lahan aktual untuk budidaya tanaman Cabai Merah termasuk kelas sesuai marginal / S3-rc,eh seluas 292,56 ha serta terdapat kelas cukup sesuai S2 - tc,wa seluas $121,88 \mathrm{ha}$, dimana faktor pembatas yang tidak dapat dilakukan upaya perbaikan adalah tekstur tanah, sedangkan faktor pembatas seperti retensi hara, ketersedian hara, ketersediaan air, dan bahaya erosi dapat dilakukan upaya perbaikan berupa : (1). Pemberian bahan organik, pengapuran, dan pemupukan yang disesuaikan dengan hasil uji tanah pada masingmasing unit lahan, dan (2). Pembuatan saluran drainase, penanaman dengan sistem zigzag, sejajar kontur, dan pembuatan teras/gludan.

\section{Daftar Pustaka}

Food and Agriculture Organization of The United Nations (FAO). 1976. A framework for land evaluation, soil resources development and concervation secvice land and water development division, Soils Bulletin, 32

Hardjowigeno, S. 2007. Ilmu Tanah. Akademika Pressindo. Jakarta.

Indranada, H.K. 1986. Pengelolaan Kesuburan Tanah. Jakarta: PT Bina Aksara
Mubekti. 2012. Evaluasi karakteristik dan kesesuaian lahan untuk komoditi unggulan perkebunan: studi kasus Kabupaten Kampar. Jurnal Teknik Lingkungan 8: 15-22.

Oldeman, L.R. 1975. The. Agrodimatic Map of Java and Madura, Bogor. Contributions from the Central Research Institute for Agriculture.

Puslittan, Badan Litbangtan, Kementerian Pertanian Republik Indonesia, 1995. Evaluasi Kesesuaian Lahan.

Rayes, M.L. 2007. Metode Inventarisasi Sumber Daya Lahan. Andi Ofset. Yogyakarta.

Ritung, S., Nugroho, K., Mulyani, A. dan Suryani, E. 2011. Petunjuk teknis evaluasi lahan untuk komoditas pertanin (Edisi revisi). Balai Besar Penelitian dan Pengembagan Sumberdaya Lahan, Badan Penelitian dan Pengembangan Pertanian, Bogor. 168 hal.

Sys, C., Van Ranst, E., Debaveye, J. and Beernaert, F. 1993. Land Evaluation. Crop Requirements Part III. Agricultural Publication No.7. General Administration for Development Corp. 1050 Brussels- Belgium.

Tarigan, A. 2015. Rehabilitasi lahan pertanian tertutup abu vulkanik erupsi Gunung Sinabung, Jurnal Pertanian Tropik 2 (3): 21-28. 